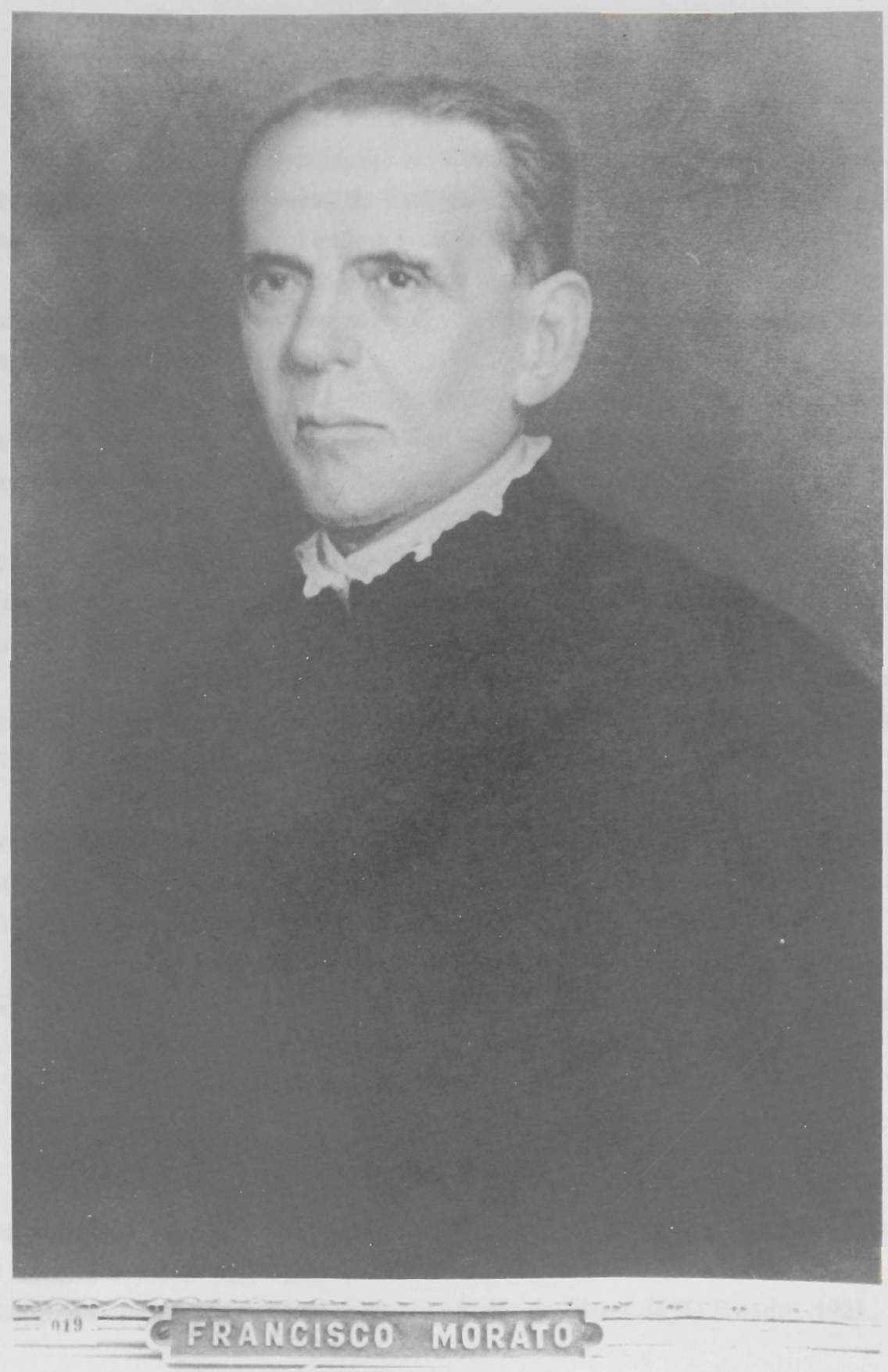





\section{FRANCISCO ANTÔNIO DE ALMEIDA MORATO}

(1935-1938)

Nasceu em Piracicaba a 17 de outubro de 1868.

Estudou Humanidades no Colégio Moretzsohn, prestando exames preparatórios no Curso Anexo da Faculdade de Direito de São Paulo, na qual matriculou-se em 1884, recebendo o grau de bacharel em 1888.

Em sua terra natal exerceu a profissão de advogado, ocupando também os cargos de promotor público, vereador, inspetor escolar e provedor da Santa Casa de Misericórdia.

Transferindo-se para São Paulo, foi um dos fundadores da Ordem dos Advogados de São Paulo, tendo sido eleito seu primeiro presidente, função que ocupou de 1916 a 1922 e de 1925 a 1927.

Aprovado em concurso, foi nomeado professor substituto da sétima seção da Faculdade de Direito de São Paulo, em 1917. Em novembro de 1918, tomou posse da cadeira e recebeu o grau de doutor. Em outubro de 1922, assumiu a cátedra de Prática do Processo Civil e Comercial.

$\mathrm{Na}$ órbita política, foi fundador do Partido Democrático, eleito deputado federal em 1927, tendo sido um dos organizadores da Frente Única de 1932, com destacado papel no Movimento Constitucionalista.

Foi membro do Instituto Histórico e Geográfico de São Paulo e presidente do Tribunal de Ética Profissional. Jubilado na cadeira de Direito Judiciário Civil, foi-lhe conferido o título de professor emérito. Após a Revolução, no período de 1932-1933 esteve exilado na França e em Portugal.

No período de 1935 a 1938, foi diretor da Faculdade de Direito de São Paulo. Recusou a presidência do Estado, aceitando porém o cargo de secretário da Justiça e Negócios do Interior na interventoria Macedo Soares.

Faleceu a 21 de maio de 1948.

\section{Obras Publicadas}

Da prescripção nas acções divisorias. S.l.p., s.c.p., 1917. These (cat. dir. proc. civil). Faculdade de Direito da USP.

Codigo de ethica profissional. São Paulo : Seção de Obras de "O Estado", 1921. 
Questões praticas de direito judiciario: imissão de posse; direito de retenção de terceiros: pareceres. Revista da Faculdade de Direito de Säo Paulo, 1932. v. 28.

Miscellanea juridica. São Paulo : s.c.p., 1945. 2 vs. 